\title{
Seasonal Trends of Polycyclic Aromatic Hydrocarbons in Particulate Matter at an Urban Site in Beijing, China
}

\author{
Yanju Liu ${ }^{1 *}$, Qingyang Liu², Xinxin Wang2, Tingting Zhang ${ }^{2}$ \\ ${ }^{1}$ Beijing Milu Ecological Research Center, Beijing, China \\ ${ }^{2}$ Beijing Center for Physical and Chemical Analysis, Beijing, China \\ Email: liuyanju@hotmail.com
}

Received December 2014

\begin{abstract}
This study was conducted to examine the impact of vehicular traffic emissions on the seasonal trends of polycyclic aromatic hydrocarbons (PAHs) concentration in particulate matter in Beijing. The $\mathbf{P M}_{10}$ and $\mathbf{P M}_{2.5}$ samples were collected at an urban site near the Third Ring Road in Beijing, China, from July 2009 to March 2010. Individual PAH concentrations at urban traffic site ranged from n.d. (below the detection limit, $0.2 \mathrm{ng} / \mathrm{m}^{3}$ ) to $558.49 \mathrm{ng} / \mathrm{m}^{3}$ of benzo(b)fluoranthene in $\mathrm{PM}_{10}$ samples and from n.d. to $177.93 \mathrm{ng} / \mathrm{m}^{3}$ also for benzo(b)fluoranthene in $\mathbf{P M}_{2.5}$ samples. Seasonal variations of PAHs compounds indicated that PAHs concentration in autumn and winter was higher than those in spring and summer. Results of PCA give four and five significant factors, which could explain $83.1 \%$ of the variation for $\mathbf{P M}_{2.5}$ and $85.3 \%$ of the variation for $\mathrm{PM}_{10}$, respectively.
\end{abstract}

\section{Keywords}

PAHs, Particulate Matter, Traffic Pollution, Beijing

\section{Introduction}

Industrialization and urbanization have promoted socio-economic development. This has, however, led to variety of environmental problems in urban areas, including contamination by polycyclic aromatic hydrocarbons (PAHs) via various pathways [1]. Airborne PAHs, either in gas or particle phases, are found to have a direct impact on human health [2]. PAHs are resistant to degradation and bio-accumulate through the food chain, thus they also may pose threat to human health over a long period. Considering the high toxicities of PAHs, it is necessary to study the concentrations, profiles and sources of PAHs in the particulate matter (PM). PAHs come from two main sources. Natural PAHs are mainly from volcanic eruptions and natural fires. Anthropogenic PAHs are mostly generated during the combustion of carbonaceous materials such as coals, gasoline and diesel [3]. Previous studies suggested that PAH concentrations increased significantly in the urban PM parts since the 1990s [4]-[7].

Beijing, the capital city of China, located in the Northern China, is a fast developing city with over 1000 years

${ }^{*}$ Corresponding author.

How to cite this paper: Liu, Y.J., Liu, Q.Y., Wang, X.X. and Zhang, T.T. (2015) Seasonal Trends of Polycyclic Aromatic Hydrocarbons in Particulate Matter at an Urban Site in Beijing, China. Journal of Geoscience and Environment Protection, 3, 10-16. http://dx.doi.org/10.4236/gep.2015.32002 
of history. PAH pollution in the particulate matter of Beijing has been reported [8]. The city consists of 14 administrative districts. As one of the busiest traffic routes in Beijing, the Third Ring Road built in the 1980s crosses five central districts, named after Haidian, Chaoyang, Chongwen, Xuanwu and Fengtai. The five districts contain the majority of the commercial, industrial and traditional areas of Beijing. Both districts of Xuanwu and Chongwen comprise the old historic centers, while Haidian, Chaoyang and Fengtai, located in the northern, eastern and southern region, and are the centers for high technology, central business and industrial district, respectively. The PM near the road was the focus of this investigation as they serve as an important reservoir of PAHs generated by traffic emission [9]. The chemical analysis of PM samples can, therefore, provide a useful and convenient initial measure of environmental quality. The aims of this work were to: 1) determine individual concentrations of PAHs profile in the PM samples including $\mathrm{PM}_{10}$ and $\mathrm{PM}_{2.5}$ collected from the Third Ring Road, 2) identify seasonal variations of PAHs to track their possible influencing factors.

\section{Methods and Materials}

\subsection{Sampling Site and PM Mass Measurement}

Influenced by the summer monsoon, Beijing experiences cold, relatively dry winter, hot and humid summer. The sampling site was located near a busy traffic line in Beijing $\left(116^{\circ} 18^{\prime} 10^{\prime \prime} 8 \mathrm{E}, 39^{\circ} 56^{\prime} 50^{\prime \prime} 7 \mathrm{~N}\right)$ (measured by GPS Etrex Vista HCX, made by GARMIN). Sampling equipments were set up on the roof of an office building with a height of $30 \mathrm{~m}$ aboveground and a distance about $30 \mathrm{~m}$ from the road/traffic. This is a very busy ring road with 6 fast tracks and 4 voeux roads; with 230 - 270 vehicles at the speed about $50 \mathrm{~km} /$ hour passing through per minute in the morning rush hour. 24-h $\mathrm{PM}_{10}$ and $\mathrm{PM}_{2.5}$ were collected onto $90 \mathrm{~mm}$ diameter quartz microfiber filters (QMA, Whatman) at a flow rate of $100 \mathrm{~L} / \mathrm{min}$, using the Smart TSP Volume Air Samplers (TH-150A type, made by Wuhan Tianhong Instrument Co.,Ltd.), equipped with different PM head for $\mathrm{PM}_{10}$ and $\mathrm{PM}_{2.5}$ respectively. The filter was replaced at 10:00 a. m. Beijing time daily through the whole sampling period, and the measurement was carried out for one month every season. In detail, samples were collected from June 10 to July 10 in summer 2009, from September 10 to 30 in autumn 2009, from December 1 to 31 in winter 2009, and from March 1 to 31 for spring of 2010.

Filters were weighed using a balance (CP225D, with accuracy of $0.01 \mathrm{mg}$, made in Sartorius, Germany), and PM mass was calculated as the mass differences before and after sampling at unit sampling volume. Filters were heated for 4 hours at $550^{\circ} \mathrm{C}$ and preserved in desiccators with humidity of $34 \%$ for 24 hours before pre-sampling weighing. After sampling, filters were kept in desiccators for 24 hours before re-weighing. During the weighing procedure, temperature was controlled at $20^{\circ} \mathrm{C}$ by air conditioning. Filters were then cut into quarters using stainless steel cutter for subsequent component analysis.

\subsection{Sample Analysis}

All the organic solvents were high performance liquid chromatography (HPLC) grade, purchased from Fisher (Fair Lawn, NJ, USA). 'Superclean' silica gel solid phase extraction columns (6 mL, $500 \mathrm{mg})$ were purchased from Supelco Inc. (Bellefonte, PA, USA). The standard with 16 PAHs (EPAM-610, $1 \mathrm{~mL}, 0.1 \mathrm{mg} / \mathrm{mL}$ in 1: 1 methanol: dichloromethane) and the 2D-labelled surrogate standards (EPA M-525-IS, $1 \mathrm{~mL}, 2.0 \mathrm{mg} / \mathrm{mL}$ in acetone), which included acenaphthylene-d10, chrysene-d12, perylene-d12 and phenanthrene-d10, were purchased from Accustandard Inc. (CT, USA).

The extraction method was as follows. Prior to ultrasonic extraction with n-hexane and dichloromethane (1: 1, $\mathrm{v} / \mathrm{v})$, the samples were spiked with 2D-labelled surrogate standards. The extracts were completely dried in a rotary evaporator and subsequently dissolved in $10 \mathrm{~mL}$ of hexane. Then, samples were drawn through the activated column through the clean column by gravity. Then, dichloromethane was used to elude the PAHs for three times ( $6 \mathrm{~mL}$ each time). The eluents was concentrated to $0.5 \mathrm{~mL}$ under a gentle nitrogen gas flow before being injected into the GC-MS.

PAHs were quantified on a Varian 350 gas chromatography coupled with Varian 240 mass spectrometer with electron impact ion (EI) source. Helium was chosen as carrier gas with a constant flow of $1.0 \mathrm{~mL} / \mathrm{min}$. The extract was injected into the injector with splitless mode, and separated on a DB-5MS fused silica capillary column. The electron emission energy was set at $70 \mathrm{eV}$. The source and ion trap temperature was set at $280^{\circ} \mathrm{C}$ and $220^{\circ} \mathrm{C}$, respectively. The oven temperature programs were as follows: started at $50^{\circ} \mathrm{C}$ retaining for $2 \mathrm{~min}$, first ramped 
to $200^{\circ} \mathrm{C}$ at speed of $10^{\circ} \mathrm{C} / \mathrm{min}$, second ramped to $260^{\circ} \mathrm{C}$ at $2^{\circ} \mathrm{C} / \mathrm{min}$, and finally ramped to $260^{\circ} \mathrm{C}$ at $5^{\circ} \mathrm{C} / \mathrm{min}$, kept for $4 \mathrm{~min}$.

\subsection{Quality Control}

Analytical methods were checked for the precision and accuracy. All the samples were analyzed three times to obtain the average level. Replicate analyses gave an error between $\pm 15 \%$. The recoveries were checked by analyzing soil and needles samples spiked with known amounts of labeled PAHs. The average recoveries of surrogates were 73.8\% (acenaphthylene-d10), 92.5\% (chrysene-d12, perylene-d12) and 83.2 (phenanthrene-d10). The spiked test showed the recoveries of 16 PAHs were from $60.2 \%$ to $114.3 \%$ with the RSD from $5.6 \%$ to $15.4 \%$.

\subsection{Data Analysis}

The measured data was processed by SPSS 18.0 and excel software.

\section{Results and Discussion}

\subsection{Total PAHs in $\mathrm{PM}_{10}$ and $\mathrm{PM}_{2.5}$}

$\mathrm{PM}_{10}$ and $\mathrm{PM}_{2.5}$ samples collected from the Third Ring Road in Beijing, each with 82 in total, were analyzed PAHs concentrations. The concentrations descriptions of 16 individual PAHs specie with their abbreviations are listed in Table 1. Individual PAH concentrations at traffic sites ranged from n.d. (below the detection limit, 0.2 $\mathrm{ng} / \mathrm{m}^{3}$ ) to $558.49 \mathrm{ng} / \mathrm{m}^{3}$ for benzo(b)fluoranthene $(\mathrm{BbF})$ in $\mathrm{PM}_{10}$ samples and from n.d. (below the detection limit) to $177.93 \mathrm{ng} / \mathrm{m}^{3}$ also for $\mathrm{BbF}$ in $\mathrm{PM}_{2.5}$ samples. Yearly average PAHs concentration in $\mathrm{PM}_{10}$ is $126.16 \mathrm{ng} / \mathrm{m}^{3}$, less than that measured as $164.6 \mathrm{ng} / \mathrm{m}^{3}$ in Xuzhou, a Chinese city in the middle of the country [10]. Meanwhile, yearly average PAHs concentration in $\mathrm{PM}_{2.5}$ is $107.18 \mathrm{ng} / \mathrm{m}^{3}$, much less than $712.4 \mathrm{ng} / \mathrm{m}^{3}$ measured in a coal producing northeast Chinese city of Fushun [11].

Table 1. Summary of PAHs concentrations in PM samples at an urban roadside site in Beijing $\left(\mathrm{ng} / \mathrm{m}^{3}\right)$.

\begin{tabular}{|c|c|c|c|c|c|c|c|c|c|}
\hline \multirow{2}{*}{ PAHs } & \multirow{2}{*}{ Abbreviation } & \multirow{2}{*}{$\begin{array}{l}\text { Ring } \\
\text { No. }\end{array}$} & \multirow{2}{*}{$\begin{array}{l}\text { Molecular } \\
\text { Formula }\end{array}$} & \multicolumn{3}{|c|}{$\mathrm{PM}_{10}$} & \multicolumn{3}{|c|}{$\mathrm{PM}_{2.5}$} \\
\hline & & & & Mean & Min & Max & Mean & Min & Max \\
\hline Naphthalene & Nap & 2 & $\mathrm{C}_{10} \mathrm{H}_{8}$ & 6.51 & 0.00 & 75.41 & 7.54 & 0.00 & 69.34 \\
\hline Phenanthrene & PA & 3 & $\mathrm{C}_{14} \mathrm{H}_{10}$ & 9.15 & 0.00 & 65.12 & 7.95 & 0.00 & 37.84 \\
\hline Pyrene & Pyr & 4 & $\mathrm{C}_{16} \mathrm{H}_{10}$ & 24.52 & 3.85 & 126.23 & 25.42 & 3.34 & 111.07 \\
\hline Indeno(1,2,3-cd)pyrene & IND & 6 & $\mathrm{C}_{22} \mathrm{H}_{12}$ & 2.05 & 0.00 & 23.94 & 1.99 & 0.00 & 19.83 \\
\hline Fluorene & Flu & 3 & $\mathrm{C}_{13} \mathrm{H}_{10}$ & 1.42 & 0.00 & 5.66 & 1.66 & 0.00 & 13.88 \\
\hline Fluoranthene & $\mathrm{FL}$ & 4 & $\mathrm{C}_{16} \mathrm{H}_{10}$ & 16.62 & 0.00 & 126.65 & 15.49 & 0.25 & 103.76 \\
\hline Dibenzo(a,h)anthrancene & DBA & 5 & $\mathrm{C}_{22} \mathrm{H}_{14}$ & 0.26 & 0.00 & 12.30 & 0.21 & 0.00 & 8.40 \\
\hline Chrysene & CHR & 4 & $\mathrm{C}_{16} \mathrm{H}_{12}$ & 13.12 & 0.00 & 352.71 & 8.10 & 0.00 & 143.59 \\
\hline Benzo(k)fluoranthene & $\mathrm{BkF}$ & 5 & $\mathrm{C}_{20} \mathrm{H}_{12}$ & 11.27 & 0.00 & 312.57 & 6.68 & 0.00 & 177.93 \\
\hline Benzo(g,h,i)perylene & BghiP & 6 & $\mathrm{C}_{22} \mathrm{H}_{12}$ & 2.01 & 0.00 & 19.54 & 2.21 & 0.00 & 18.64 \\
\hline Benzo(b)fluoranthene & $\mathrm{BbF}$ & 5 & $\mathrm{C}_{20} \mathrm{H}_{12}$ & 19.44 & 0.00 & 558.49 & 11.89 & 0.00 & 176.02 \\
\hline Benzo(a)pyrene & $\mathrm{BaP}$ & 5 & $\mathrm{C}_{20} \mathrm{H}_{12}$ & 6.89 & 0.00 & 191.96 & 3.37 & 0.00 & 43.87 \\
\hline Benzo(a)anthracene & $\mathrm{BaA}$ & 4 & $\mathrm{C}_{22} \mathrm{H}_{14}$ & 6.89 & 0.00 & 58.35 & 7.50 & 0.00 & 78.71 \\
\hline Anthracene & Ant & 3 & $\mathrm{C}_{14} \mathrm{H}_{10}$ & 4.96 & 0.00 & 53.62 & 4.25 & 0.00 & 24.79 \\
\hline Acenaphthene & Acp & 3 & $\mathrm{C}_{12} \mathrm{H}_{10}$ & 0.70 & 0.00 & 3.73 & 1.44 & 0.00 & 31.84 \\
\hline Acenaphthylene & AcPy & 3 & $\mathrm{C}_{12} \mathrm{H}_{8}$ & 0.35 & 0.00 & 4.85 & 1.48 & 0.00 & 56.77 \\
\hline$\sum 16 \mathrm{PAHs}$ & & & & 126.16 & & & 107.18 & & \\
\hline
\end{tabular}

n.d.: below the detection limit $\left(0.2 \mathrm{ng} / \mathrm{m}^{3}\right)$; Min: Minimum; Max: Maximum. 


\subsection{Seasonal Variations of PAHs in PM Samples}

As shown in Figure 1 and Table 2, for $\mathrm{PM}_{10}$ samples, the concentrations of phenanthrene (PA), pyrene (Pyr),

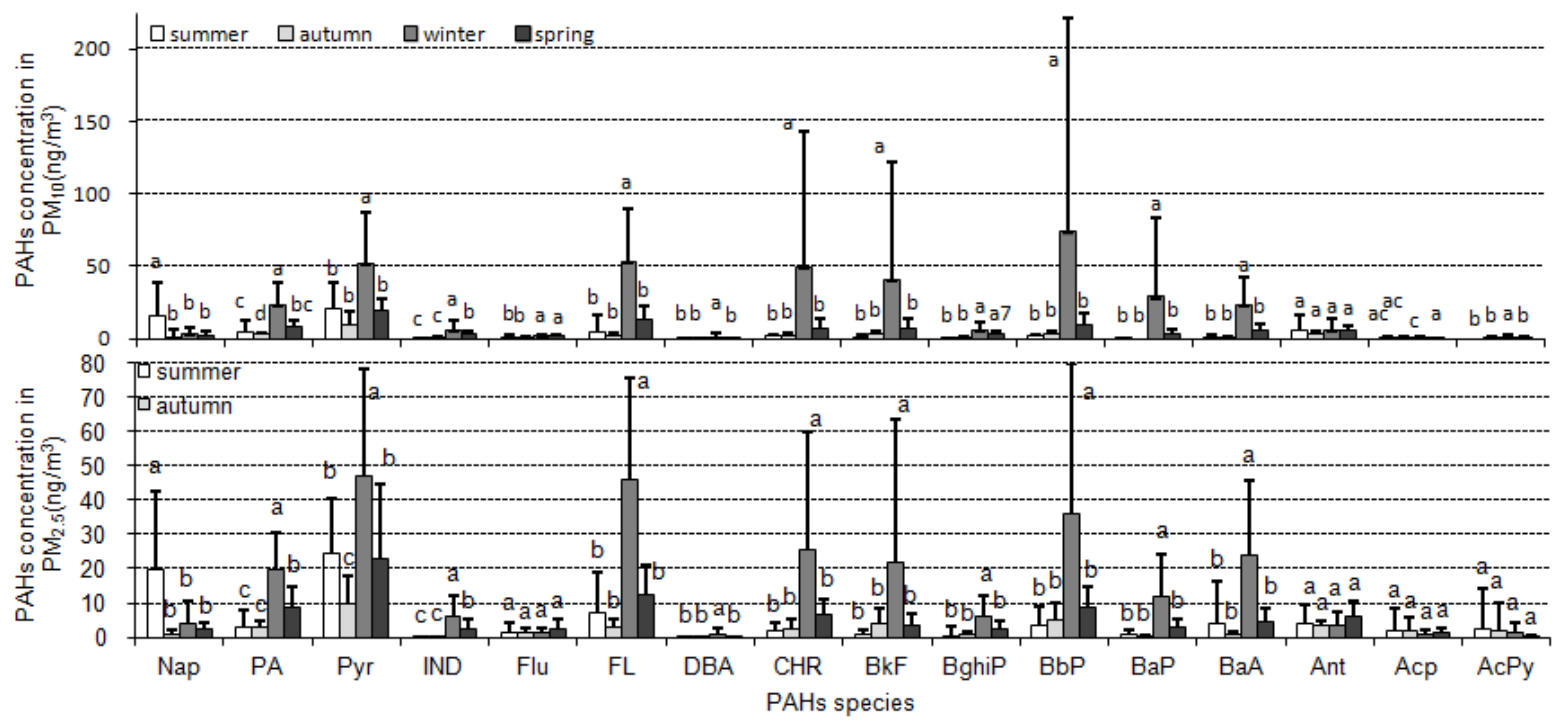

Figure 1. Seasonal variation of $\mathrm{PAHs}$ in $\mathrm{PM}_{10}$ and $\mathrm{PM}_{2.5}$. The same letter means no significant difference among the sub-groups.

Table 2. Seasonal variation of $\mathrm{PAHs}$ in $\mathrm{PM}_{10}$ and $\mathrm{PM}_{2.5}$ samples $\left(\mathrm{ng} / \mathrm{m}^{3}\right)$.

\begin{tabular}{|c|c|c|c|c|c|c|c|c|c|c|c|c|c|c|c|c|}
\hline \multirow{3}{*}{ PAHs } & \multicolumn{8}{|c|}{$\mathrm{PM}_{10}$} & \multicolumn{8}{|c|}{$\mathrm{PM}_{2.5}$} \\
\hline & \multicolumn{2}{|c|}{$\begin{array}{l}\text { summer } \\
(\mathrm{n}=25)\end{array}$} & \multicolumn{4}{|c|}{ autumn $(\mathrm{n}=18)$ winter $(\mathrm{n}=17)$} & \multicolumn{2}{|c|}{ spring $(\mathrm{n}=22)$} & \multicolumn{2}{|c|}{$\begin{array}{l}\text { summer } \\
(\mathrm{n}=24)\end{array}$} & \multicolumn{4}{|c|}{ autumn $(n=19)$ winter $(n=17)$} & \multicolumn{2}{|c|}{ spring $(\mathrm{n}=22)$} \\
\hline & Mean & S. D. & Mean & S. D. & Mean & S. D. & Mean & S. D. & Mean & S. D. & Mean & S. D. & Mean & S. D. & Mean & S. D. \\
\hline Nap & 15.97 & 22.15 & 1.37 & 4.43 & 3.13 & 3.88 & 2.57 & 2.13 & 19.84 & 22.64 & 1 & 1.13 & 4.23 & 6.21 & 2.34 & 1.77 \\
\hline PA & 4.65 & 8.45 & 2.71 & 1.03 & 23.05 & 15.97 & 8.79 & 4.24 & 3.13 & 4.88 & 2.88 & 1.73 & 19.79 & 10.93 & 8.44 & 6.09 \\
\hline Pyr & 20.48 & 17.9 & 9.98 & 8.54 & 51.9 & 34.93 & 19.86 & 7.28 & 24.56 & 16.15 & 9.99 & 7.92 & 46.92 & 31.3 & 23.06 & 21.48 \\
\hline IND & 0 & 0.02 & 0.38 & 0.49 & 5.84 & 6.87 & 2.82 & 2.9 & 0.03 & 0.12 & 0.35 & 0.45 & 5.86 & 6.46 & 2.57 & 2.66 \\
\hline Flu & 1.14 & 1.15 & 0.7 & 0.25 & 1.83 & 1.22 & 2.02 & 0.72 & 1.54 & 2.7 & 1.1 & 1.3 & 1.52 & 0.97 & 2.4 & 2.63 \\
\hline FL & 4.88 & 11.89 & 2.37 & 1.68 & 52.82 & 37.43 & 13.65 & 8.33 & 7.15 & 11.85 & 2.77 & 2.45 & 45.72 & 30.14 & 12.23 & 8.75 \\
\hline DBA & 0.01 & 0.05 & 0 & 0.01 & 1.19 & 2.98 & 0.05 & 0.08 & 0.04 & 0.08 & 0.01 & 0.05 & 0.86 & 2.03 & 0.07 & 0.13 \\
\hline CHR & 1.52 & 1.53 & 2.02 & 2.34 & 49.17 & 94.41 & 7.51 & 6.11 & 1.87 & 2.58 & 2.15 & 3.34 & 25.47 & 34.39 & 6.63 & 4.49 \\
\hline $\mathrm{BkF}$ & 0.95 & 1.15 & 3.37 & 2.09 & 40.36 & 81.34 & 6.98 & 6.29 & 0.95 & 1.3 & 4.02 & 4.17 & 21.93 & 41.6 & 3.44 & 3.57 \\
\hline BghiP & 0.01 & 0.03 & 0.54 & 0.51 & 5.65 & 5.6 & 2.67 & 2.56 & 0.53 & 2.5 & 0.58 & 0.89 & 6.11 & 5.76 & 2.43 & 2.56 \\
\hline $\mathrm{BbP}$ & 1.69 & 1.09 & 3.6 & 1.34 & 74.62 & 147.01 & 9.92 & 7.54 & 3.26 & 5.5 & 5 & 4.88 & 36.19 & 43.85 & 8.47 & 6.04 \\
\hline $\mathrm{BaP}$ & 0.06 & 0.17 & 0 & 0 & 28.81 & 54.27 & 3.37 & 3.07 & 0.63 & 1.48 & 0.14 & 0.62 & 11.68 & 12.39 & 2.74 & 2.74 \\
\hline $\mathrm{BaA}$ & 1.24 & 1.19 & 0.69 & 0.68 & 23.56 & 19.21 & 5.5 & 4.73 & 3.92 & 12.19 & 0.82 & 0.73 & 23.69 & 22.12 & 4.67 & 3.91 \\
\hline Ant & 5.29 & 10.48 & 3.36 & 1.5 & 5.8 & 8.33 & 5.26 & 4.21 & 3.8 & 5.55 & 3.38 & 1.42 & 3.66 & 3.68 & 5.94 & 4.52 \\
\hline Acp & 0.6 & 0.73 & 0.64 & 0.78 & 0.55 & 0.72 & 1 & 0.55 & 1.94 & 6.4 & 1.63 & 4.34 & 0.81 & 1.41 & 1.23 & 1.66 \\
\hline AcPy & 0 & 0 & 0.24 & 1.01 & 1.12 & 1.55 & 0.23 & 0.77 & 2.49 & 11.58 & 1.94 & 8.21 & 1.31 & 3.06 & 0.11 & 0.51 \\
\hline$\sum 16 \mathrm{PAHs}$ & 58.49 & & 31.97 & & 369.4 & & 92.2 & & 75.68 & & 37.76 & & 255.75 & & 86.77 & \\
\hline
\end{tabular}

Notes: S.D. refers to standard deviation. 
indeno(1,2,3-cd)pyrene (IND), fluoranthene (FL), dibenzo-(a,h)anthrancene (DBA), chrysene (CHR), benzo(k)fluoranthene $(\mathrm{BkF})$, benzo(b)fluoranthene $(\mathrm{BbF})$, benzo(a)-pyrene $(\mathrm{BaP})$, benzo(a)anthracene $(\mathrm{BaA})$ and acenaphthylene (AcPy) were much higher in winter than in other seasons $(p<0.05)$, whereas the concentration of naphthalene (Nap) was higher in summer than in other seasons. Concentrations of fluorene (Flu) and benzo $(\mathrm{g}, \mathrm{h}, \mathrm{i})$ perylene (BghiP) were higher in spring and winter than those in summer and autumn. In addition, no significant seasonal trends of anthracene (Ant) were found. For $\mathrm{PM}_{2.5}$ samples, the concentrations of PA, Pyr, IND, FL, DBA, CHR, BkF, BghiP, BbF, BaP, BaA were much higher in winter than in other seasons $(p<0.05)$. Similar to that in $\mathrm{PM}_{10}$, the concentration of Nap in $\mathrm{PM}_{2.5}$ was also higher in summer than in other seasons. Otherwise, the concentrations of Flu, Ant, acenaphthene (Acp) and AcPy did not show significant seasonal variations (Figure 1 and Table 2).

\subsection{Source Apportionment of PAHs}

\subsubsection{Principal Component Analysis (PCA)}

Results of PCA give four and five significant PCs (eigenvalues $>1$ ), which explains $83.1 \%$ of the variation for $\mathrm{PM}_{2.5}$ data $\left(43.5 \%, 17.1 \%, 14.8 \%\right.$ and $7.8 \%$, respectively) and $85.4 \%$ of the variation for $\mathrm{PM}_{10}$ data $(43.6 \%$, $18.2 \%, 9.7 \%, 7.6 \%$ and 6.3\%, respectively). As shown in Table 3, four or five factors of PAH congeners can be observed, corresponding to the different carbon rings, from di- to six cyclic-rings molecular.

\subsubsection{Ratio Analysis Methods}

According to previous opinion [12], both PAHs of $\mathrm{PM}_{2.5}$ and $\mathrm{PM}_{10}$ in winter mainly originated from fossil fuels burning based on the ratio of Ant/(Ant + Phe $)<0.3$, while in other three seasons, Ant/(Ant + Phe $)>0.3$, implying PAHs were possibly from biomass fuel combustion (Table 4). Pankow [13] thought that PAHs originate from combustion source at $\mathrm{BaA} /(\mathrm{BaA}+\mathrm{Chr})>0.35$, mainly from oil at $<0.2$, and from both at $0.2-0.35$. Ac-

Table 3. Principal component analysis of PAHs in PM samples.

\begin{tabular}{|c|c|c|c|c|c|c|c|c|c|}
\hline \multirow{2}{*}{ PAHs } & \multicolumn{5}{|c|}{ Components in $\mathrm{PM}_{10}$} & \multicolumn{4}{|c|}{ Components in $\mathrm{PM}_{2.5}$} \\
\hline & 1 & 2 & 3 & 4 & 5 & 1 & 2 & 3 & 4 \\
\hline Nap & & & 0.307 & & 0.862 & & & 0.05 & 0.739 \\
\hline PA & 0.879 & 0.231 & & 0.11 & 0.053 & 0.942 & 0.131 & & \\
\hline Pyr & 0.778 & 0.156 & & 0.137 & 0.337 & 0.818 & 0.088 & & \\
\hline IND & 0.652 & 0.572 & 0.041 & & & 0.602 & & & 0.156 \\
\hline Flu & 0.517 & 0.419 & 0.414 & 0.15 & 0.14 & 0.258 & 0.837 & 0.044 & 0.088 \\
\hline FL & 0.869 & 0.21 & & 0.056 & 0.161 & 0.948 & 0.002 & & \\
\hline DBA & 0.587 & & 0.077 & & & 0.641 & & 0.622 & 0.052 \\
\hline $\mathrm{CHR}$ & 0.786 & & 0.134 & 0.074 & & 0.846 & & 0.478 & 0.012 \\
\hline $\mathrm{BkF}$ & 0.743 & & 0.118 & 0.126 & & 0.673 & & 0.661 & \\
\hline BghiP & 0.642 & 0.613 & & & & 0.637 & & & 0.256 \\
\hline $\mathrm{BbP}$ & 0.773 & & 0.135 & 0.082 & & 0.887 & & 0.392 & 0.066 \\
\hline $\mathrm{BaP}$ & 0.787 & & 0.135 & & & 0.763 & 0.033 & & 0.144 \\
\hline $\mathrm{BaA}$ & 0.866 & 0.203 & & & 0.064 & 0.79 & 0.033 & & \\
\hline Ant & 0.106 & 0.048 & & 0.516 & 0.125 & 0.175 & 0.345 & & \\
\hline Acp & 0.089 & 0.388 & 0.629 & 0.625 & & 0.165 & 0.929 & 0.227 & 0.146 \\
\hline $\mathrm{AcPy}$ & 0.463 & 0.54 & 0.213 & 0.263 & & 0.165 & 0.883 & 0.193 & 0.167 \\
\hline
\end{tabular}


Table 4. Ratio between typical individual PAHs concentrations.

\begin{tabular}{cccccc}
\hline PM & Ratio & Summer & Autumn & Winter & Spring \\
\hline Ant/(Ant + Phe) & 0.53 & 0.55 & 0.2 & 0.37 \\
BaA/(BaA + CHR) & 0.45 & 0.25 & 0.32 & 0.42 \\
IcdP/BghiP & 0 & 0.38 & 5.84 & 2.82 \\
BaP/BghiP & 6 & 0 & 5.1 & 0.5 & 0.41 \\
FLA/(FLA + Pyr) & 0.19 & 0.19 & 0.16 & 0.41 \\
Ant/(Ant + Phe) & 0.55 & 0.54 & 0.48 & 0.41 \\
BaA/(BaA + CHR $)$ & 0.68 & 0.28 & 5.86 & 2.57 \\
IcdP/BghiP & 0.03 & 0.35 & 1.91 & 1.13 \\
BaP/BghiP & 1.19 & 0.24 & 0.49 & 0.35 \\
\hline
\end{tabular}

cording to this, PAHs of $\mathrm{PM}_{10}$ in autumn and winter, together with $\mathrm{PAHs}$ of $\mathrm{PM}_{2.5}$ in autumn were sourced from both combustion and oil, while PAHs of $\mathrm{PM}_{10}$ in summer and spring, together with $\mathrm{PAHs}$ of $\mathrm{PM}_{2.5}$ in summer, winter and spring were from combustion. PAHs in both $\mathrm{PM}_{10}$ and $\mathrm{PM}_{2.5}$ were from coal combustion based on $\mathrm{BaP} /$ BghiP of 0.9 - 6.6 in all seasons except autumn, when the BaP/BghiP ratio was even less than $0.3-0.44$, a traffic source range [14]. Based on the opinion of Kavouras et al. [15], the Fla/(Fla + Pyr) of $\mathrm{PM}_{10}$ and $\mathrm{PM}_{2.5}$ in this study is around to 0.4 , representing for oil source in spring and winter. In addition, IcdP is a marker of diesel combustion and could tell the type of vehicle fuel [14]. IcdP/BghiP value near 0.22 implies PAHs sourced from gasoline combustion, 0.50 from diesel and 1.30 from kerosene. In this study, PAHs in autumn is between 0.22 to 0.50 , implying mixed sources of gasoline and diesel. While in winter, IcdP/BghiP value is much higher than 1.30 , implying other PAHs sources involved, which agrees with fossil fuels combustion source in winter.

\section{Conclusion}

In this study, individual PAHs concentrations in PM samples at an urban roadside site in Beijing were analyzed through seasons. The results show that the inputs of potentially toxic contaminants increased because of rapid economic development. Seasonal variations of PAHs compounds indicated $68.7 \%$ individual species of PAHs concentrations in winter were higher than those in other seasons. In contrast, Nap concentrations in both PM $_{10}$ and $\mathrm{PM}_{2.5}$ were highest in summer, but the source is uncertain. In addition, four and five significant factors were identified to influence the variations of $\mathrm{PAHs}$ concentration in $\mathrm{PM}_{10}$ and $\mathrm{PM}_{2.5}$, respectively.

\section{Acknowledgements}

This work was supported by the Natural National Science Foundation of China (No. 41175104, 41475133 and 41305110).

\section{References}

[1] Flowers, S.H., Rieth, V.J., Cogliano, G.L., et al. (2002) Health Assessment of Polycyclic Aromatic Hydrocarbon Mixtures: Current Practices and Future Direction. Polycyclic Aromatic Compound, 22, 811-818. http://dx.doi.org/10.1080/10406630290103960

[2] Zheng, M., Salmon, L.G., Schauer, J.J., et al. (2005) Seasonal Trends in $\mathrm{PM}_{2.5}$ Sources Contributions in Beijing, China. Atmospheric Environment, 39, 3967-3976. http://dx.doi.org/10.1016/j.atmosenv.2005.03.036

[3] Obiri, S., Cobbina, S.J., Armah, F.A., et al. (2011) Quantification and Characterization of Vehicle-Based Polycyclic Aromatic Hydrocarbons in Street Dust from the Tamale Metropolis, Ghana. Environmental Science and Pollution Research, 18, 1166-1173. http://dx.doi.org/10.1007/s11356-011-0465-9

[4] Yang, S.Y.N., Connell, D.W., Hawker, D.W., et al. (1991) Polycyclic Aromatic Hydrocarbons in Air, Soil and Vegetation in the Vicinity of an Urban Roadway. Science of the Total Environment, 102, 229-240. 
http://dx.doi.org/10.1016/0048-9697(91)90317-8

[5] Jiang, Y.F. (2009) Levels, Composition Profiles and Sources of Polycyclic Aromatic Hydrocarbons in Urban Soil of Shanghai, China. Chemosphere, 75, 1112-1118. http://dx.doi.org/10.1016/j.chemosphere.2009.01.027

[6] Agarwal, T. (2009) Concentration Level, Pattern and Toxic Potential of PAHs in Traffic c Soil of Delhi, India. Journal of Hazardous Materials, 171, 894-900. http://dx.doi.org/10.1016/j.jhazmat.2009.06.081

[7] Amagai, T., Takahashi, Y. and Masushita, H. (1999) A Survey on Polycyclic Aromatic Hydrocarbons in Soil in Chiang-Mai, Thailand. Environment International, 25, 563-572. http://dx.doi.org/10.1016/S0160-4120(99)00026-4

[8] Fu, S., Li. K., Xia. X.J., et al. (2009) Polycyclic Aromatic Hydrocarbons Residues in Sandstorm Depositions in Beijing, China. Bulletin of Environmental Contamination and Toxicology, 82, 162-166. http://dx.doi.org/10.1007/s00128-008-9537-z

[9] Lv, J.G., Shi, R.G., Cai, Y.M., et al. (2010) Assessment of Polycyclic Aromatic Hydrocarbons Pollution in Soil of Suburban Areas in Tianjin, China. Bulletin of Environmental Contamination and Toxicology, 85, 5-9.

[10] Chen, F., Qin, C. and Zhong, Q. (2013) Source Apportionment of Polycyclic Aromatic Hydrocarbon in Xuzhou. Environmental Science \& Ecology, 22, 1916-1921.

[11] Zhao, L., Zhang, J., Li, L., Zhao, M., et al. (2014) Study of Pollution Characteristic of PAHs in PM 2.5 in Fushun Wanghua District. Applied Chemical Industry, 43, 1336-1338.

[12] Sun, R., Zhu, T. and Bai, Z. (1997) Source Apportionment and Indentification of Polycyclic Aromatic Hydrocarbons on Airborn Particulate. Urban Environ. Urban Ecol., 10, 27-31.

[13] Pankow, J.F. (1994) An Absorption Model of Gas/Particle Partitioning of Organic Compounds in the Atmosphere. Atmospheric Environment, 28, 185-188. http://dx.doi.org/10.1016/1352-2310(94)90093-0

[14] Li, X., Guo, X., Liu, X., et al. (2008) Pollution Characteristics of PAHs in the Atmospheric Aerosols in Winter Time of Beijing. Environmental Chemistry, 27, 490-493.

[15] Kavouras, I.G., Koutrakis, P., TsaPakis, M., et al. (2001) Source Apportionment of Urban Particulate Aliphatic and Polynuclear Aromatic Hydrocarbons (PAHs) Using Multivariate Methods. Environmental Science \& Technology, 35, 2288-2294. http://dx.doi.org/10.1021/es001540z 